\title{
Salutogenesis: Sense of Coherence in Childhood and in Families
}

\author{
Orly Idan, Orna Braun-Lewensohn, Bengt Lindström, and Malka Margalit
}

\section{Introduction}

Our goals were to present the significance of the salutogenic conceptualization to the development and education of children, exploring in depth not only children with typical development, but also children with special needs, their schools, families, and community environments. In order to understand the developmental perspective of resiliency, we reviewed studies examining sense of coherence (SOC) at children's different developmental stages, from infants and toddlers through preschool children to school-aged children (up to 12 years of age). A comprehensive review of the literature (from 2000 to 2013) on SOC and children demonstrated a diverse range of themes: SOC within the child's contextual environments-family, school, peers, and community, and SOC as a predictor of children's health and health behavior.

First, a short description of the infant, preschool, and early childhood stage is presented, focusing on the challenges of this developmental stage. Second, the adaptation of the original SOC scale to children and its characteristics is described. Third, a summary of the studies reflecting challenges in the application of the salutogenic conceptualization to education with a focus on the

O. Idan $(\bowtie)$

Psychology of Intergroup Conflict and Reconciliation Lab, School of Psychology, Interdisciplinary Center (IDC), Herzliya, Israel

e-mail: oidan@idc.ac.il

O. Braun-Lewensohn

Conflict Management and Resolution Program, Ben-Gurion University of the Negev, Beer Sheva, Israel

e-mail: ornabl@bgu.ac.il

B. Lindström

NTNU Center for Health Promotion and Resources, Norwegian University of Science and Technology, Trondheim, Norway

e-mail: bengtblind@hotmail.com

M. Margalit

Tel Aviv University; Peres Academic Center, Rehovot, Israel

e-mail: malka@post.tau.ac.il experiences of children is discussed, alongside the risk factors, protective factors, and interventional implications related to current trends in the SOC studies within different contextual perspectives. And finally, we conclude by identifying future research directions.

\section{Infant, Preschool, and Early Childhood Development}

Studies on early childhood recognize that infancy and early childhood are distinct developmental periods in which young children differ significantly from older children, adolescents, and adults in terms of cognitive skills, language and communication, self-regulation, and socioemotional functioning (Mowder, Rubinson, \& Yasik, 2009). The science of early childhood development demonstrates that the foundations for sound mental health are built early in life, as early experiences shape the architecture of the developing brain (Miller \& Kinsbourne, 2012). These important experiences include children's relationships with parents, caregivers, relatives, teachers, and peers, which play a critical role in shaping social, emotional, and cognitive development. Recent research indicates that early intervention can have a positive impact on the trajectory of common emotional or behavioral problems as well as outcomes for children with adversities and disorders (National Scientific Council on the Developing Child, 2012). Adverse experiences early in life, particularly for vulnerable children, have been shown to predict the emergence of later physical and mental health problems (Edwards, Holden, Felitti, \& Anda, 2003). Although mental health challenges for young children share many biological and behavioral characteristics with those of older children and adults, there are several aspects which differentiate early childhood from later developmental stages. First, emotional health for young children is very strongly influenced by their environment and the nature of their relationships and the support or 
risks these relationships confer. Therefore, it is essential to examine the quality of the children's environments and relationships in order to tap the risks for adversaries and the protective factors that may assist in promoting positive mental and physical health. Second, cognitive, social, and emotional characteristics are all intertwined within the architecture of the brain, and these capacities vary at different developmental stages. Children understand, manage, think, feel, and talk about their experiences differently at different ages. These developmental differences are important to understanding the behavioral and emotional risks and protective factors involved. Finally, in early childhood, it can be challenging to distinguish short-lived deviations in behavior from persistent problems, or typical differences in maturation from developmental delays (Rubin, Bukowski, \& Parker, 2006).

From birth, children develop their abilities to experience and express a diverse range of emotions, as well as their capacity to cope with and manage different feelings (Thompson \& Lagattuta, 2006). The development of these capabilities occurs at the same time as a wide range of highly visible skills in mobility, cognition, and communication (Thompson, 2001). The foundations of social competence that are developed in the first five years are linked to emotional well-being and affect a child's ability to functionally adapt in school later on and form promoting relationships during adolescence and adulthood (Cassidy \& Shaver, 1999). Therefore, it is important to address children's affective and cognitive aspects. Failure to address difficulties in the socioemotional domain may result in missed opportunities for interventions at critical periods (National Scientific Council on the Developing Child, 2004).

The emotional experiences of newborns and young infants occur for the most while interacting with their caregivers. Associations between positive emotions and the availability of responsive caregivers are strengthened during infancy in both behavior and brain architecture (Cassidy, 1994). Toddlers and preschool children depend on their emerging capacities to interpret their own personal experiences and understand what others are doing and thinking, as well as to interpret the distinctions between different responses to them. By the end of the preschool years, children who have acquired emotional regulation skills, have the capacity to use their awareness of their own and others' feelings to interact on a daily basis (Thompson \& Lagattuta, 2006). Studies have shown how the interrelated development of emotion and cognition relies on the emergence, maturation, and interconnection of complex neural circuits in multiple areas of the brain (Davidson et al., 2002). The emotional development of young children is correlated to the characteristics of the environments in which they live, including their families, school, and community (Reid, Patterson, \& Snyder, 2002).
In order to dynamically understand the changing experiences of children at different age groups (preschool and elementary) within diverse environments (family, school, peer group, and community), and examine how children understand, manage, and find meaning in their world, a Children's Sense of Coherence Scale (CSOC) based on the three components of the SOC construct was developed.

\section{Children's Sense of Coherence Scale}

The Children's Sense of Coherence Scale (CSOC) (Margalit \& Efrati, 1995) is an adaptation of the Antonovsky Orientation to Life (Sense of Coherence-SOC) Scale (Antonovsky, 1987). In line with the sense of coherence construct and the adults' scale, a children's version (CSOC) was developed, field tested and revised several times at the Special Education Laboratory in Tel-Aviv University.

Due to the children's young age and reservations regarding the ability of children to comprehend the construct and scale, it was decided to develop a scale that would meet the unique characteristics of the target population. The scale was developed in collaboration with Aaron and Helen Antonovsky. The scale included distractors relating to the children's life and activities. The language, the order of the words, the nature of the examples, and distracters were examined in order to ensure the comprehension of young children and the inclusion of age appropriate contents. Since its development, several additional versions have been used, such as for junior high school students, omitting the distracter items. Example: "I'm interested in lots of things" and "I'm interested in lots of things in my class" (for a school based research, or "at home"-for a family based research). In general, distracters were coherent with the given culture to which the children belonged to.

The children's scale was tested on children aged five to adolescents. Comprehension was examined using unstructured interviews; stability was verified by a series of retests. Conceptually, the items were derived from SOC-29 and the three components of the SOC. This consisted of 16 primary items and three filler items on a four-point Likert scale (the range was reduced to 4 from 'never' (1) to 'always' (4)). Scores ranged from 16 to 64, with items describing the children's feeling of confidence in their world, as expressed in their sense of comprehensibility-understanding their environment (i.e., "I feel that I don't know what to do in class"); sense of manageability-feelings of control, and confidence that when help is needed, it will be available (i.e., "when I want something, I'm sure I'll get it"); and meaningfulness interest in investing efforts in different 
tasks (i.e., "I'm interested in lots of things") (Alpha $=.72$ ). Similar to the SOC scoring procedures, a high score reflected a high level of CSOC.

Studies using the CSOC explored children's personal and contextual resources and their ability to perceive family, social, and educational environments as structured and meaningful realities. The following section presents studies that used CSOC.

\section{Studies on SOC During Childhood}

A systematic search for studies on children and SOC between the years 2000 and 2013 in online databases (PsychoInfo, Ebsco, Proquest, APApsycnet, SocioFile, SAGE, Web of Science, and PubMed) using keywords (sense of coherence, salutogenesis, children, and family) and Boolean operators, presented 37 studies from 14 countries. Table 13.1 summarizes the studies.

Two major foci emerged from the review of the studies: Children's SOC within the family, school, peer group, and community environments and CSOC as a predictor of children's health and health behavior. The studies relating to CSOC and different contextual environments may be divided into three age groups/developmental stages: the preschool age stage, the elementary school age stage, and a prolonged stage from infant to adolescence/adulthood focusing on families of children with special needs.

\section{SOC and the Child's Environments: Family, School, Peers, and Community}

The salutogenic paradigm focuses on promoting growth and adjustment. The following research deals with the contributions of children's environments: families, friends, and school systems, to the adjustment of children with typical development and children with special needs.

The resilience approach defines assumptions about the critical predictors of the full potential of children to learn and to thrive in diverse settings regardless of personal and environmental challenges and risk factors (Damon, 2004). A major role of resilient research is to identify the complex transactions and processes among internal and external (risk and protective) factors that affect children's resilience and sense of coherence (Margalit, 2003).

Sense of coherence at the preschool age stage. Children at various ages, with a high sense of coherence, may perceive their day-to-day experiences as comprehensible and manageable. In order to explore the sense of coherence of typically developing preschool children and preschool children with special needs, studies examined the children and their parents within different contextual settings (Al-Yagon,
2003; Margalit, 1998; Most, Al-Yagon, Tur-Kaspa, \& Margalit, 2000). In a sample of 187 preschool children aged 4.9-6.3 years, children who were identified as at risk for developing learning disabilities, even before they were formally diagnosed and labeled, had experienced a lower sense of coherence, had fewer friends, and were less accepted by their peers. The sense of coherence assessment revealed the children's heterogeneity, and even among the group of typical developing children a small subgroup could be defined with a very low sense of coherence and many social challenges. In addition, in line with the salutogenic paradigm, special attention was given to a small subgroup of children within the group of children at risk whose sense of coherence was high. The relatively small extreme groups may add to the understanding of the development of coherence from early developmental stages (Margalit, 1998).

The children with a risk for developing learning disabilities received a special tutoring program on an individual and small group basis during school time by the special education teachers. The focus was on language enrichment and basic learning skills. The sense of coherence of a subgroup of these preschool children $(N=67)$ was tested. Significant differences were noted in the comparisons between the sense of coherence scores at the beginning of the intervention and at the mid-year evaluation. However, no significant differences were found between mid-year and the end of the year. The correlations between the first and the second assessment of children's sense of coherence were significant (0.34) and between the second and the third assessment (0.32) as well. It can be concluded that at this age stage, there was some level of flexibility in the children's sense of coherence, and remedial work that focused training on the delayed academic, language, and cognitive functioning was related to increased sense of coherence, and narrowing the gap with the typical developing group (Margalit, 1998).

Language difficulties and social emotional challenges are often considered as two separate risk factors at the preschool age stage. A study of preschool children explored the relations between children's sense of coherence, loneliness, and phonological awareness. Phonological awareness consists of language skills such as awareness to the structure of sounds in words and sentences. Research reports that they predict reading acquisition (Most et al., 2000). The study examined the phonological awareness skills, loneliness, sense of coherence, and peer acceptance among 98 children aged 5.0-6.4 years old. Children at risk had lower achievements as a group on the phonological awareness measures; reported lower CSOC, viewed themselves as lonelier, and were less accepted by their peers.

Family ecology is comprised of parental, familial, and environmental characteristics that may affect the capacity of the family to provide optimal care (Greenberg, Speltz, \& 
Table 13.1 Studies (2000-2013) on SOC during childhood

\begin{tabular}{|c|c|c|c|c|c|}
\hline Author & Year & Place & Population & Variables & Results \\
\hline 1. Al-Yagon & 2003 & Israel & $\begin{array}{l}145 \text { mother child dyads of } \\
5-6.5 \text {-year-old } \\
\text { kindergartners with/ } \\
\text { without mild } \\
\text { developmental delays }\end{array}$ & $\begin{array}{l}\text { Children: developmental delay } \\
\text { status, temperament, gender, } \\
\text { loneliness, SOC, friendship } \\
\text { nomination, attachment security } \\
\text { style; mother's SOC, family } \\
\text { cohesion and adaptability }\end{array}$ & $\begin{array}{l}\text { Child's SOC demonstrated that } \\
\text { the attachment pattern mediator } \\
\text { variable significantly explained } \\
15 \% \text { of the variance among } \\
\text { children with developmental } \\
\text { delays. Children having secure } \\
\text { attachment reported higher levels } \\
\text { of SOC than children having } \\
\text { insecure attachment. }\end{array}$ \\
\hline 2. Al-Yagon & 2007 & Israel & $\begin{array}{l}110 \text { mother child dyads of } \\
8-11 \text {-year-old school } \\
\text { children with/without LD }\end{array}$ & $\begin{array}{l}\text { Children: LD and non-LD group, } \\
\text { gender, loneliness, SOC, } \\
\text { attachment security style, hope; } \\
\text { mothers: coping, affect, } \\
\text { experience in close relationships, } \\
\text { child behavior }\end{array}$ & $\begin{array}{l}\text { Mothers' low use of avoidant } \\
\text { coping strategies and less } \\
\text { avoidance in close relationships } \\
\text { with significant others were } \\
\text { found to moderate the effect of } \\
\text { children's disabilities on } \\
\text { children's levels of loneliness, } \\
\text { hope, and secure attachment. }\end{array}$ \\
\hline 3. Al-Yagon & 2008 & Israel & $\begin{array}{l}58 \text { mother child dyads of } \\
8-11 \text {-year-old school } \\
\text { children }\end{array}$ & $\begin{array}{l}\text { Children: loneliness, SOC, } \\
\text { mother-rated behavior; mothers: } \\
\text { SOC, attachment style, } \\
\text { loneliness }\end{array}$ & $\begin{array}{l}\text { Maternal SOC significantly } \\
\text { contributed to all child } \\
\text { socioemotional adjustment } \\
\text { measures and attachment scores. }\end{array}$ \\
\hline 4. Al-Yagon & 2010 & Israel & $\begin{array}{l}205 \text { mother child dyads of } \\
\text { 8-12-year-old school } \\
\text { children with/without LD }\end{array}$ & $\begin{array}{l}\text { Children: LD and non-LD group, } \\
\text { gender, SOC, attachment } \\
\text { security style, hope, effort; } \\
\text { mothers: experiences in close } \\
\text { relationships, affect, child } \\
\text { behavior }\end{array}$ & $\begin{array}{l}\text { Children's adjustment and SOC } \\
\text { mediated associations between } \\
\text { maternal emotional resources } \\
\text { and children's well-adjusted } \\
\text { functioning. The significantly } \\
\text { lower SOC among children with } \\
\text { LD emphasized this coping } \\
\text { resource. }\end{array}$ \\
\hline 5. Al-Yagon & 2011 & Israel & $\begin{array}{l}205 \text { father child dyads of } \\
8-12 \text {-year-old school } \\
\text { children with/without LD }\end{array}$ & $\begin{array}{l}\text { Children: LD and non-LD group, } \\
\text { gender, SOC, loneliness, } \\
\text { attachment security style, hope, } \\
\text { effort; fathers: coping, SOC, } \\
\text { child behavior }\end{array}$ & $\begin{array}{l}\text { The mediating role of CSOC } \\
\text { emerged for both groups in the } \\
\text { association between fathers' } \\
\text { resources and children's well- } \\
\text { adjusted functioning. The } \\
\text { significantly lower SOC among } \\
\text { children with LD emphasized } \\
\text { this coping resource. }\end{array}$ \\
\hline 6. Al-Yagon & 2012 & Israel & $\begin{array}{l}3128-12 \text {-year-old school } \\
\text { children with/without LD } \\
\text { and their parents }\end{array}$ & $\begin{array}{l}\text { Children: LD and non-LD group, } \\
\text { gender, SOC, loneliness, } \\
\text { attachment security style, hope; } \\
\text { parents: child behavior }\end{array}$ & $\begin{array}{l}\text { Children who felt securely } \\
\text { attached to both parents reported } \\
\text { a higher global orientation or } \\
\text { enduring tendency to see the } \\
\text { world as comprehensible, } \\
\text { manageable, and meaningful } \\
\text { than children who felt securely } \\
\text { attached to only one parent or to } \\
\text { neither parent. In contrast, } \\
\text { children who exhibited insecure } \\
\text { attachment to both parents } \\
\text { appeared to be the most } \\
\text { vulnerable in forming coping } \\
\text { resources. }\end{array}$ \\
\hline $\begin{array}{l}\text { 7. Al-Yagon and } \\
\text { Cinamon }\end{array}$ & 2008 & Israel & $\begin{array}{l}96 \text { mother child dyads of } \\
8-12 \text {-year-old school } \\
\text { children with/without LD }\end{array}$ & $\begin{array}{l}\text { Children: LD and non-LD group, } \\
\text { gender, attachment security } \\
\text { style; mothers: experiences in } \\
\text { close relationships, affect, work } \\
\text { family relations, SOC, family } \\
\text { cohesion, and adaptability }\end{array}$ & $\begin{array}{l}\text { Higher maternal perceptions of } \\
\text { the world as comprehensible, } \\
\text { manageable, and meaningful } \\
\text { contributed significantly to } \\
\text { children's secure attachment and } \\
\text { level of connection, closeness } \\
\text { and involvement between the } \\
\text { family members. }\end{array}$ \\
\hline $\begin{array}{l}\text { 8. Al-Yagon and } \\
\text { Margalit }\end{array}$ & 2006 & Israel & $\begin{array}{l}2663 \text { rd graders with/ } \\
\text { without reading } \\
\text { difficulties }\end{array}$ & $\begin{array}{l}\text { Loneliness, SOC, children's } \\
\text { appraisal of teacher as a secure } \\
\text { base }\end{array}$ & $\begin{array}{l}\text { Children's perception of their } \\
\text { teacher as their secure base } \\
\text { correlated significantly with } \\
\text { higher levels of SOC and lower } \\
\text { levels of loneliness. }\end{array}$ \\
\hline
\end{tabular}


Table 13.1 (continued)

\begin{tabular}{|c|c|c|c|c|c|}
\hline Author & Year & Place & Population & Variables & Results \\
\hline $\begin{array}{l}\text { 9. Al-Yagon and } \\
\text { Mikulincer }\end{array}$ & 2004 & Israel & $\begin{array}{l}1968-11 \text {-year-old school } \\
\text { children with/without LD; } \\
23 \text { homeroom teachers }\end{array}$ & $\begin{array}{l}\text { Children: LD and non-LD group, } \\
\text { gender, loneliness, SOC, } \\
\text { attachment security style; } \\
\text { teachers: ratings of children's } \\
\text { academic functioning }\end{array}$ & $\begin{array}{l}\text { Secure attachment classification } \\
\text { correlated significantly with } \\
\text { higher levels of SOC and lower } \\
\text { levels of loneliness. }\end{array}$ \\
\hline $\begin{array}{l}\text { 10. Berntsson and } \\
\text { Gustafsson }\end{array}$ & 2000 & Sweden & $\begin{array}{l}11637-12 \text {-year-old } \\
\text { school children }\end{array}$ & $\begin{array}{l}\text { Psychosomatic complaints, } \\
\text { mental stability, family } \\
\text { activities, parents' health status, } \\
\text { gender, parents' social class, } \\
\text { education, income, ethnicity, } \\
\text { employment, and family } \\
\text { structure }\end{array}$ & $\begin{array}{l}\text { Predictors of psychosomatic } \\
\text { complaints were mother's health, } \\
\text { child's mental stability, contacts } \\
\text { with peers, long-term illness, and } \\
\text { via other factors, parents' SOC, } \\
\text { social competence, and school } \\
\text { satisfaction. }\end{array}$ \\
\hline 11. Bonanato et al. & 2009 & Brazil & $\begin{array}{l}546 \text { mother child dyads of } \\
5 \text {-year-old preschool } \\
\text { children }\end{array}$ & $\begin{array}{l}\text { Mothers' SOC, oral health status, } \\
\text { social class }\end{array}$ & $\begin{array}{l}\text { Mothers with lower levels of } \\
\text { SOC were more likely to have } \\
\text { children with decayed teeth or } \\
\text { filled teeth regardless of the } \\
\text { child's social class and gender. }\end{array}$ \\
\hline 12. Dabrowska & 2003 & Poland & $\begin{array}{l}77 \text { parents of children } \\
\text { with CP and } 62 \text { parents of } \\
\text { normally developing } \\
\text { children }\end{array}$ & Coping, stress, SOC & $\begin{array}{l}\text { Parents of children with cerebral } \\
\text { palsy, reporting higher levels of } \\
\text { SOC, less often used avoidance, } \\
\text { wishful thinking and resignation } \\
\text { as coping strategies than parents } \\
\text { reporting lower levels of SOC. }\end{array}$ \\
\hline 13. Dabrowska & 2008 & Poland & $\begin{array}{l}128 \text { fathers of children } \\
\text { with and without } \\
\text { developmental } \\
\text { disabilities }\end{array}$ & SOC, coping & $\begin{array}{l}\text { Fathers of children with } \\
\text { developmental disabilities } \\
\text { reported lower levels of SOC } \\
\text { more frequently and used } \\
\text { strategies of avoidance compared } \\
\text { to fathers with higher levels of } \\
\text { SOC that used confrontation } \\
\text { more frequently and positive } \\
\text { reappraisal and problem solving } \\
\text { behavior. }\end{array}$ \\
\hline $\begin{array}{l}\text { 14. Efrati-Virtzer } \\
\text { and Margalit }\end{array}$ & 2009 & Israel & $\begin{array}{l}337 \text { school children } \\
\text { grades } 3-6 \text { with/without } \\
\text { behavior difficulties; } \\
47 \text { teachers }\end{array}$ & $\begin{array}{l}\text { Children: SOC, loneliness, peer } \\
\text { nominations; teachers: } \\
\text { hyperactive behavior, aggressive } \\
\text { behavior, academic } \\
\text { achievements }\end{array}$ & $\begin{array}{l}\text { Teachers evaluated students with } \\
\text { BD as achieving lower academic } \\
\text { grades and displaying higher } \\
\text { levels of hyperactive behavior } \\
\text { and aggression. Children with } \\
\text { BD were less accepted by their } \\
\text { peers, reported lower levels of } \\
\text { SOC and higher levels of } \\
\text { loneliness. Students that were } \\
\text { rated by their teachers as } \\
\text { revealing higher levels of } \\
\text { hyperactive and aggressive } \\
\text { behavior experienced lower } \\
\text { levels of personal coherence. }\end{array}$ \\
\hline 15. Einav et al. & 2012 & Israel & $\begin{array}{l}111 \text { mother-child dyads of } \\
\text { infants aged } 3-24 \text { months } \\
\text { with developmental } \\
\text { delays }\end{array}$ & $\begin{array}{l}\text { SOC, family cohesion and } \\
\text { adaptability, coping, hope }\end{array}$ & $\begin{array}{l}\text { Mothers with high levels of SOC } \\
\text { and with high coping strategies } \\
\text { felt more hopeful. In families } \\
\text { characterized by flexibility and } \\
\text { open to changes, mothers } \\
\text { reported higher levels of coping } \\
\text { that contributed to their hope } \\
\text { measure. Family cohesion was } \\
\text { interrelated with mothers' SOC, } \\
\text { but not directly related to coping } \\
\text { or to hope. Cohesion was related } \\
\text { to hope only indirectly, mediated } \\
\text { through mothers' SOC. }\end{array}$ \\
\hline
\end{tabular}


Table 13.1 (continued)

\begin{tabular}{|c|c|c|c|c|c|}
\hline Author & Year & Place & Population & Variables & Results \\
\hline 16. Forinder et al. & 2005 & Sweden & $\begin{array}{l}52 \text { patients aged } 9-22 \\
\text { (at least } 3 \text { years following } \\
\text { stem cell transplant) }\end{array}$ & $\begin{array}{l}\text { Late effects in each of eight } \\
\text { predefined problem categories, } \\
\text { patient activity, SOC, quality of } \\
\text { life }\end{array}$ & $\begin{array}{l}\text { The scores obtained on SOC for } \\
\text { younger children (aged 9-12) } \\
\text { showed that the SCT group has } \\
\text { an SOC on par with that of both } \\
\text { the norm groups and other } \\
\text { chronically ill children. The } \\
\text { mean value for the younger } \\
\text { children in the SCT group was on } \\
\text { par with that of the norm group. }\end{array}$ \\
\hline 17. Groholt et al. & 2003 & $\begin{array}{l}\text { The five } \\
\text { Nordic } \\
\text { countries }\end{array}$ & $\begin{array}{l}95242-17 \text {-year-old } \\
\text { children of which } 35 \% \\
\text { were coresponders (with } \\
\text { their parents), } 2 \% \\
\text { children }\end{array}$ & $\begin{array}{l}\text { Parental SOC, parental health, } \\
\text { marital status, education, } \\
\text { socioeconomic status, income, } \\
\text { child chronic health condition, } \\
\text { child gender }\end{array}$ & $\begin{array}{l}\text { Compared to the higher social } \\
\text { classes, low levels of SOC were } \\
\text { more common in the lower } \\
\text { classes. The association of child } \\
\text { chronic health with parental poor } \\
\text { SOC was found to be disability } \\
\text { specific (diabetes, epilepsy, } \\
\text { psychiatric problems). }\end{array}$ \\
\hline 18. Hedov et al. & 2002 & Sweden & $\begin{array}{l}207 \text { parents of children } \\
\text { (aged 3.5-7) with Down's } \\
\text { syndrome, } 237 \text { parents of } \\
\text { healthy children }\end{array}$ & $\begin{array}{l}\text { Parents' groups, SOC, parental } \\
\text { self-perceived stress, frequency } \\
\text { of gainful employment, amount } \\
\text { to time spend ton child care }\end{array}$ & $\begin{array}{l}\text { Mean SOC scores of the parents } \\
\text { of children with DS did not differ } \\
\text { from those of the control group. } \\
\text { Parents from both groups who } \\
\text { experienced lower stress in } \\
\text { parenthood had a stronger SOC. }\end{array}$ \\
\hline 19. Hintermair & 2004 & Germany & $\begin{array}{l}235 \text { mothers of children } \\
\text { aged } 1-13 \text { with hearing } \\
\text { impairments }\end{array}$ & $\begin{array}{l}\text { SOC, stress, life satisfaction, } \\
\text { social support, age, gender, } \\
\text { education, means of } \\
\text { communication with children }\end{array}$ & $\begin{array}{l}\text { Mothers with a stronger SOC had } \\
\text { an advantage in coping with the } \\
\text { experience of raising a deaf and } \\
\text { hard of hearing child over } \\
\text { mothers with lower SOC scores. } \\
\text { SOC was of greater importance } \\
\text { than experienced social support. }\end{array}$ \\
\hline 20. Honkinen et al. & 2005 & Finland & $\begin{array}{l}123112 \text {-year-old school } \\
\text { children }\end{array}$ & $\begin{array}{l}\text { Profession of parents, gender, } \\
\text { SOC, physical activity, weight, } \\
\text { academic achievements, social } \\
\text { support, class climate, } \\
\text { psychosomatic symptoms }\end{array}$ & $\begin{array}{l}\text { SOC and variables of social } \\
\text { support were found significantly } \\
\text { associated with perceived health. } \\
\text { Physical exercise and SOC were } \\
\text { associated with perceived health } \\
\text { and father's occupation and poor } \\
\text { SOC was found to be } \\
\text { independently associated with } \\
\text { relatively poor health. }\end{array}$ \\
\hline 21. Jellesma et al. & 2006 & Netherlands & $\begin{array}{l}1538-13 \text {-year-old school } \\
\text { children at three levels of } \\
\text { somatic complaints }\end{array}$ & $\begin{array}{l}\text { Groups: Low somatic } \\
\text { complaints, many somatic } \\
\text { complaints, clinical group; } \\
\text { happiness, anger, fear, sadness, } \\
\text { depressiveness, emotion } \\
\text { awareness, SOC }\end{array}$ & $\begin{array}{l}\text { The clinical group and the } \\
\text { children with many somatic } \\
\text { complaints reported more } \\
\text { negative moods on the anger, } \\
\text { sadness and fear scale, more } \\
\text { difficulty differentiating } \\
\text { emotions and a lower SOC. }\end{array}$ \\
\hline 22. Krause & 2011 & Germany & $\begin{array}{l}2265-10 \text {-year-old school } \\
\text { children; longitudinal }\end{array}$ & $\begin{array}{l}\text { Health promotion by self-worth } \\
\text { reinforcement program, SOC, } \\
\text { feeling of self-worth, sense of } \\
\text { belonging }\end{array}$ & $\begin{array}{l}\text { Developing sense of coherence } \\
\text { in promoting mental health in } \\
\text { school children was perceived } \\
\text { fundamental and most effective } \\
\text { in the early years of childhood } \\
\text { requiring training of } \\
\text { professionals within the school. }\end{array}$ \\
\hline 23. Liberman et al. & 2013 & Israel & $\begin{array}{l}\text { 50 5-6-year-old school } \\
\text { children with/without } \\
\text { developmental } \\
\text { coordination disorder }\end{array}$ & $\begin{array}{l}\text { Gender, mother education, } \\
\text { family income, place of living, } \\
\text { movement, children's partaking } \\
\text { (completed by parents for aged } \\
\text { 4-6.5), performance skills, SOC, } \\
\text { hope, effort }\end{array}$ & $\begin{array}{l}\text { Levels of SOC, hope and effort } \\
\text { in children with DCD were lower } \\
\text { than their typically developing } \\
\text { peers. The explanatory variables } \\
\text { (SOC, hope and effort, motor } \\
\text { skills, and processing skills) did } \\
\text { not predict either the diversity or } \\
\text { the frequency measures of } \\
\text { participation. }\end{array}$ \\
\hline
\end{tabular}


Table 13.1 (continued)

\begin{tabular}{|c|c|c|c|c|c|}
\hline Author & Year & Place & Population & Variables & Results \\
\hline 24. Londal & 2010 & Norway & $\begin{array}{l}368-9 \text {-year-old children } \\
\text { participating in an after } \\
\text { school program; } \\
4 \text { months, qualitative }\end{array}$ & Play, SOC & $\begin{array}{l}\text { Play in the ASP had considerable } \\
\text { potential of promoting the } \\
\text { children's SOC. Most of the } \\
\text { children in the study experienced } \\
\text { their world as comprehensible, } \\
\text { manageable, and meaningful. } \\
\text { Negative thoughts and feelings } \\
\text { were reduced during bodily play. } \\
\text { Play offered particularly strong } \\
\text { opportunities for the children } \\
\text { themselves to shape outcomes, } \\
\text { and interact with children, } \\
\text { promoting their SOC. }\end{array}$ \\
\hline 25. Mak et al. & 2006 & Hong Kong & $\begin{array}{l}157 \text { mothers of children } \\
\text { with autism (aged 1-28) }\end{array}$ & $\begin{array}{l}\text { Severity of autistic symptoms, } \\
\text { SOC, parenting attitudes, } \\
\text { parenting stress, age, education, } \\
\text { marital status, income }\end{array}$ & $\begin{array}{l}\text { Mothers with a higher level of } \\
\text { SOC reported less stress than } \\
\text { those with a lower level. SOC } \\
\text { had a moderating effect on the } \\
\text { association between symptom } \\
\text { severity and parenting stress. }\end{array}$ \\
\hline $\begin{array}{l}\text { 26. Margalit, } \\
\text { Al-Yagon and } \\
\text { Kleitman }\end{array}$ & 2006 & Israel & $\begin{array}{l}80 \text { mothers of children } \\
\text { aged } 2-39 \text { months } \\
\text { exhibiting delayed } \\
\text { development }\end{array}$ & $\begin{array}{l}\text { SOC, family cohesion and } \\
\text { adaptability, mood, coping, } \\
\text { parenting stress }\end{array}$ & $\begin{array}{l}\text { Mothers from noncohesive } \\
\text { families with lower SOC } \\
\text { experienced higher levels of } \\
\text { stress than mothers from } \\
\text { cohesive families with higher } \\
\text { SOC. Mothers from noncohesive } \\
\text { families with lower SOC } \\
\text { experienced lower levels of } \\
\text { positive mood than mothers from } \\
\text { cohesive families with high } \\
\text { SOC. }\end{array}$ \\
\hline 27. Most et al. & 2000 & Israel & $\begin{array}{l}98 \text { 5-6.4-year-old } \\
\text { preschool children with/ } \\
\text { without risk for } \\
\text { developing LD }\end{array}$ & $\begin{array}{l}\text { Groups (at risk and not at risk), } \\
\text { gender, phonological awareness } \\
\text { skills, loneliness, SOC, peer } \\
\text { acceptance }\end{array}$ & $\begin{array}{l}\text { Children at risk scored lower on } \\
\text { phonological awareness, } \\
\text { loneliness, SOC, peer } \\
\text { acceptance. The largest number } \\
\text { of children at risk was in the } \\
\text { group with lowest levels of SOC } \\
\text { and phonological awareness } \\
\text { skills. }\end{array}$ \\
\hline 28. Nammontri et al. & 2013 & Thailand & $\begin{array}{l}25710-12 \text {-year-old } \\
\text { school children; } \\
133 \text { intervention group }\end{array}$ & $\begin{array}{l}\text { Clinical variables, oral health- } \\
\text { related quality of life, SOC, oral } \\
\text { health beliefs }\end{array}$ & $\begin{array}{l}\text { Greater SOC predicted positive } \\
\text { health beliefs and fewer } \\
\text { symptoms. Intervention provided } \\
\text { evidence that SOC influences } \\
\text { oral health-related quality of life. }\end{array}$ \\
\hline 29. Natvig et al. & 2006 & Norway & $\begin{array}{l}4116 \text { school children aged } \\
11,13 \text {, and } 15 .\end{array}$ & $\begin{array}{l}\text { Age, gender, SOC, supportive } \\
\text { school climate, learning } \\
\text { conditions, school-related stress }\end{array}$ & $\begin{array}{l}\text { Analyses of all resources and } \\
\text { stress factors, the strongest and } \\
\text { most adverse association with } \\
\text { SOC were seen in the relation } \\
\text { with feeling pressured by } \\
\text { schoolwork. Among girls, this } \\
\text { association was strongest for the } \\
\text { youngest group. School-related } \\
\text { factors represent both resource } \\
\text { and stress factors of importance } \\
\text { for the SOC. }\end{array}$ \\
\hline $\begin{array}{l}\text { 30. Oelofsen and } \\
\text { Richardson }\end{array}$ & 2006 & $\begin{array}{l}\text { United } \\
\text { Kingdom }\end{array}$ & $\begin{array}{l}104 \text { fathers and mothers } \\
\text { of preschool children } \\
\text { (average age } 43.8 \\
\text { months) with/without } \\
\text { developmental } \\
\text { disabilities }\end{array}$ & $\begin{array}{l}\text { Family structure, parental age, } \\
\text { socioeconomic classification, } \\
\text { child gender, child age, SOC, } \\
\text { parenting stress, parental health } \\
\text { status, parental social support }\end{array}$ & $\begin{array}{l}\text { Parents of children with DD } \\
\text { reported parenting stress within } \\
\text { the clinical range, weaker SOC, } \\
\text { and poorer health than parents of } \\
\text { children without DD. Mothers of } \\
\text { children with DD reported poorer } \\
\text { health, higher levels of parenting } \\
\text { stress and weaker SOC than their } \\
\text { partners. }\end{array}$ \\
\hline
\end{tabular}


Table 13.1 (continued)

\begin{tabular}{|c|c|c|c|c|c|}
\hline Author & Year & Place & Population & Variables & Results \\
\hline $\begin{array}{l}\text { 31. Olsson and } \\
\text { Hwang }\end{array}$ & 2002 & Sweden & $\begin{array}{l}429 \text { fathers and mothers } \\
\text { of children aged } 0-16 \\
\text { with/without intellectual } \\
\text { disability }\end{array}$ & Parental group, SOC, depression & $\begin{array}{l}\text { Parents of children with ID who } \\
\text { reported low levels of SOC were } \\
\text { more depressed than control } \\
\text { parents with low levels of SOC. } \\
\text { No relation was found between } \\
\text { the age of the child and SOC } \\
\text { levels in parents of children with } \\
\text { ID. }\end{array}$ \\
\hline $\begin{array}{l}\text { 32. Pisula } \\
\text { and } \\
\text { Kossakowska }\end{array}$ & 2010 & Poland & $\begin{array}{l}45 \text { couples of parents to } \\
\text { children aged } 3-7 \text { with/ } \\
\text { without autism }\end{array}$ & $\begin{array}{l}\text { Parental gender, education, } \\
\text { employment, time spend caring } \\
\text { for the child, SOC, ways of } \\
\text { coping }\end{array}$ & $\begin{array}{l}\text { Parents of children with autism } \\
\text { had a lower level of the total } \\
\text { SOC, meaningfulness, and } \\
\text { manageability compared with } \\
\text { controls and used escape } \\
\text { avoidance coping more often. } \\
\text { SOC level was positively } \\
\text { associated with seeking social } \\
\text { support and self-controlling and } \\
\text { negatively with accepting } \\
\text { responsibility and positive } \\
\text { reappraisal. }\end{array}$ \\
\hline 33. Ray et al. & 2009 & Finland & $\begin{array}{l}772 \text { parent child dyads of } \\
10-11 \text {-year-old school } \\
\text { children }\end{array}$ & $\begin{array}{l}\text { Children: meal patterns, food } \\
\text { frequency intake; parents: SOC, } \\
\text { eating patterns }\end{array}$ & $\begin{array}{l}\text { A weaker parental SOC was } \\
\text { associated with children's } \\
\text { irregular meal pattern, more } \\
\text { frequent intake of energy-rich } \\
\text { foods, and less frequent intake of } \\
\text { nutrient-rich foods. }\end{array}$ \\
\hline $\begin{array}{l}\text { 34. Sharabi, } \\
\text { Levi, and } \\
\text { Margalit }\end{array}$ & 2012 & Israel & $\begin{array}{l}287 \text { 10-11.6-year-old } \\
\text { school children }\end{array}$ & $\begin{array}{l}\text { Loneliness, SOC, hope, effort, } \\
\text { family cohesion, and adaptability }\end{array}$ & $\begin{array}{l}\text { Four family profiles were } \\
\text { identified: Children in the two } \\
\text { cohesive families' clusters } \\
\text { reported the lowest levels of } \\
\text { loneliness and the highest levels } \\
\text { of personal strengths. Children } \\
\text { within noncohesive family } \\
\text { clusters reported the highest } \\
\text { levels of loneliness and lowest } \\
\text { levels of SOC. }\end{array}$ \\
\hline 35. Sivberg & 2002 & & $\begin{array}{l}37 \text { families, } 66 \text { parents of } \\
\text { children with and without } \\
\text { autism }\end{array}$ & $\begin{array}{l}\text { Coping, coping behavior, strain, } \\
\text { SOC }\end{array}$ & $\begin{array}{l}\text { Parents of children with autism } \\
\text { reported low levels of SOC. } \\
\text { Lower levels of coping were } \\
\text { associated with higher levels of } \\
\text { strain on the family system and } \\
\text { the level of strain on the family } \\
\text { system was greater in the } \\
\text { families with a child with an } \\
\text { ASD. }\end{array}$ \\
\hline $\begin{array}{l}\text { 36. Svavarsdottir } \\
\text { et al. }\end{array}$ & 2005 & Iceland & $\begin{array}{l}76 \text { American families } \\
\text { ( } 75 \text { mothers and } \\
62 \text { fathers) and } \\
103 \text { Icelandic families } \\
\text { (103 mothers and } \\
74 \text { fathers) }\end{array}$ & $\begin{array}{l}\text { Family adaptation, family } \\
\text { hardiness, SOC, caregiving } \\
\text { demands, family demands, } \\
\text { severity of illness }\end{array}$ & $\begin{array}{l}\text { SOC and family hardiness } \\
\text { predicted family adaptation. } \\
\text { Icelandic mothers perceived their } \\
\text { family's adaptation more } \\
\text { favorably than American } \\
\text { mothers. Regarding fathers, } \\
\text { family demands predicted } \\
\text { adaptation. SOC moderated the } \\
\text { effect of family demands on } \\
\text { adaptation for both parents. }\end{array}$ \\
\hline 37. Torsheim et al. & 2001 & Norway & $\begin{array}{l}1592 \text { grade } 6,1534 \text { grade } \\
8,1605 \text { grade } 10 \text { children }\end{array}$ & $\begin{array}{l}\text { Health complaints/symptoms, } \\
\text { school-related stress, SOC }\end{array}$ & $\begin{array}{l}\text { Age group comparisons revealed } \\
\text { that the association between } \\
\text { SOC and stress weakened with } \\
\text { age. Association between SOC } \\
\text { and health complaints grew } \\
\text { stronger. }\end{array}$ \\
\hline
\end{tabular}


DeKlyan, 1993). Olson (2000) identified cohesion and adaptability as two major parameters for evaluating the functioning of a family. Cohesion refers to the extent of connection, closeness, and involvement between the family members. Adaptability reflects the family's capability to change as an adaptation to developmental and external pressures (Olson, 1986, 2000). A family system has been considered balanced when it demonstrates moderate scores on these two dimensions. In a study examining SOC, attachment security style, loneliness, and temperament of 145 children aged 5-6.5 with and without developmental delays, and their mothers' SOC and family cohesion and adaptability, children having secure attachment to their mothers reported higher levels of SOC than children having insecure attachment (Al-Yagon, 2003).

In summary, the studies on preschool children identified SOC as a meaningful developing protective factor that differentiated between children with typical development and high risk children, even before their formal assessment and measurable academic challenges.

Sense of coherence at the elementary school age stage. The transfer to elementary schools expands the variability of the factors that affect and are affected by the children's sense of coherence. Children's academic success, social competence, and effective coping capabilities contribute to their well-being and adjustment during that period, while academic, social, and behavior difficulties may be considered risk factors. Interactions with teachers and peers have a profound impact on the children's life quality. Multiple studies examined the relations between children's sense of coherence and their family; their perceptions of teachers' support, peer friendships, and their overall school experience, revealing the complex and multivariate interactions at the elementary school age stage (Al-Yagon, 2007, 2008, 2010, 2011, 2012; Al-Yagon \& Cinamon, 2008; Al-Yagon \& Margalit, 2006; Al-Yagon \& Mikulincer, 2004; EfratiVirtzer \& Margalit, 2009; Liberman, Ratzon, \& Bart, 2013; Sharabi, Levi, \& Margalit, 2012).

In order to further clarify the role of teachers for understanding children's sense of coherence, the attachment conceptualization (that was developed for children-mothers' relations) was adapted to schools' relationships. Children's perceptions of the teachers as a source of secure base were examined, and the results revealed that secure attachment patterns expressed in the development of close relationships with teachers predicted children's SOC and loneliness (Al-Yagon \& Margalit, 2006; Al-Yagon \& Mikulincer, 2004). Children, who felt that their teachers were more available to them and more accepting, reported higher levels of sense of coherence and lower feelings of loneliness.

In another study (Efrati-Virtzer \& Margalit, 2009), the characteristics of children with behavior difficulties were examined (behavior difficulties included verbal and physical aggression toward children and objects). The age range of these children was 9-12 years and they were compared with children with no adjustment problems from the same classes. Results revealed that the behavior difficulties contributed to the explanation of social and academic functioning and were linked to social difficulties-in terms of lower peer acceptance and increased rejection by children in their classes, as well as to lower academic achievement. Children with disruptive behavior also reported lower levels of CSOC. Those children with higher CSOC revealed emotional selfregulation and participated in fewer behavior conflicts at school. It is not clear whether lower SOC was the outcome of the multiple academic, social, and behavior difficulties or predicted them. These studies proposed to treat the SOC as a protective factor that in several studies it was negatively related to loneliness, social rejection, and academic challenges. A lower sense of coherence was consistently related with higher levels of loneliness, lower social status, and lower academic functioning. In addition, students with lower levels of coherence were less accepted by their peers and rated as more rejected by them. Furthermore, students who were rated by their teachers as revealing higher levels of hyperactive and aggressive behavior experienced lower levels of personal coherence.

The study of social relations at school provided additional validation to the complexity of the interacting variables. The most common approach for exploring children's status in their class requests children to nominate their best friends (and those that they do not like) as measures of social acceptance and rejection. The construct of reciprocal positive nomination (reciprocal friendship) attracted increased research attention, since it provided information on mutual perceptions, reflecting the interpersonal attraction and liking where within a pair of children each one selected the other as a friend (Yugar \& Shapiro, 2001). If mutual positive nomination was an important indicator in reflecting friendship and explaining decreased alienation experience in schools, the reciprocal negative nomination (mutual selection within a dyad of children of the least liked child in the class) extended the understanding of increased experience of social isolation, identified enemies in classes and enhanced feelings of social exclusion and loneliness. It is not surprising that they were related to lower SOC (EfratiVirtzer \& Margalit, 2009).

Research on elementary school children with and without developmental delays and their families identified SOC as playing a significant protective role during the first year at school. In a study on 50 5-6-year-old school children with and without developmental coordination disorder (DCD), levels of CSOC, hope, and effort in children with DCD were lower than their typically developing peers. Significant correlations were found between CSOC to the children's involvement in daily activities in a variety of environments. 
The CSOC was related to the children's independence and enjoyment from participation in age appropriate social and leisure activities (Liberman et al., 2013).

The relations between children's SOC and families' characteristics. Several studies have shown that maternal coping resources moderated the effect of children's learning disabilities on secure attachment, levels of loneliness, feelings of hope, and future expectations. The degree to which the learning disability affected the children's socioemotional academic competence and social interrelations was related to the type of coping their mothers employed and their reliance on social support (Al-Yagon, 2007, 2008, 2010, 2011, 2012; Al-Yagon \& Cinamon, 2008): Maternal SOC significantly contributed to the child's socioemotional adjustment measures and attachment scores (Al-Yagon, 2008); children's adjustment and SOC mediated associations between maternal emotional resources and children's well-adjusted functioning. The significantly lower SOC among children with LD emphasized this coping resource (Al-Yagon, 2010); studies also recognized the significance of children's relations not only with mothers, but also with fathers. The mediating role of CSOC emerged for children with and without learning disabilities in the association between fathers' resources and children's welladjusted functioning (Al-Yagon, 2011); children who felt securely attached to both parents reported a higher global orientation or enduring tendency to see the world as comprehensible, manageable, and meaningful than children who felt securely attached to only one parent or to neither parent. In contrast, children who exhibited insecure attachment to both parents appeared to be the most vulnerable in forming coping resources (Al-Yagon, 2012; Al-Yagon \& Cinamon, 2008).

In a study on 287 10-12-year-old school children, four family profiles were identified: children in the cohesive families' clusters reported the lowest levels of loneliness and the highest levels of CSOC, whereas children within noncohesive family clusters reported the highest levels of loneliness and the lowest levels of CSOC (Sharabi et al., 2012).

In conclusion, during elementary school, children acquired basic learning skills, established positive and negative relations with teachers and peers, and their functioning predicted their life quality, as well as presenting special academic and behavior challenges. At this age stage, SOC was shown to provide a unique and relatively stable index of children's social and emotional adjustment and well-being. The entrance to high schools and to the adolescence age stage not only provided extended opportunities, but also revealed continued difficulties and new challenges.

A study of the Norwegian education system explored elementary through junior high school children focusing on age and gender comparisons with regard to school-related stress and resources and their relations to the SOC construct. The sample consisted of 4116 school children aged 11, 13, and 15. SOC was related to feeling pressured by schoolwork, social support from peers and expectations. Among girls, this association was strongest for the youngest group. School-related factors were shown to represent both resource and stress factors related to the SOC (Natvig, Hanestad, \& Samdal, 2006).

From infancy to adolescenceladulthood: Families of children with special needs. Children with special needs are considered a source of distress to their families. Their increased levels of stress reflect their emotional reactions to the unexpected and challenging reality of having children with developmental disabilities and behavior challenges. The fathers' and mothers' SOC reflects the impacts of the prolonged stress, but at the same time reveals their parental resources that may be conceptualized as resources that serve as protective factors (Margalit, 1994).

Research on infants and preschool children with developmental delays and their families (Einav, Levi, \& Margalit, 2012; Hedov, Anneren, \& Wikblad, 2002; Margalit, Al-Yagon, \& Kleitman, 2006; Oelofsen \& Richardson, 2006; Pisula \& Kossakowska, 2010) identified the parents' SOC as meaningful for the development of their children. In a study of 111 mother-child dyads of infants aged 3-24 months with developmental delays, mothers with high levels of SOC and with high coping strategies felt more hopeful. The family cohesion (the mothers' perceptions that their family members were close to one another and provided support when needed) was interrelated with mothers' SOC. Cohesion was related to hopeful thinking only indirectly, mediated through mothers' SOC. Only for mothers, who reported high levels of SOC, was the family support meaningful in the prediction of hopeful thinking (Einav et al., 2012).

Mothers from noncohesive families with lower SOC experienced higher levels of stress than mothers from cohesive families with higher SOC in a study examining SOC, family cohesion and adaptability, mood, coping, and parenting stress of 80 mothers of children aged 2-39 months exhibiting delayed development. Furthermore, mothers from noncohesive families with lower SOC experienced lower levels of positive mood than mothers from cohesive families with high SOC (Margalit et al., 2006). Oelofsen and Richardson (2006) studied both fathers and mothers of preschool children with developmental disabilities (DD) and found that parents of children with DD reported parenting stress within the clinical range, lower SOC, and poor health than the comparison group-parents of children without DD. The study's results focused attention on the mothers who as the major care giving parent, experienced more stress than the fathers and reported more health problems, and lower SOC than the fathers. 
Studies focusing on parents to children with special needs emphasized the significance of SOC in relation to parenting stress: parents of children with cerebral palsy, reporting higher levels of SOC, less often used avoidance, wishful thinking, and resignation as coping strategies than parents reporting lower levels of SOC (Dabrowska, 2003); parents of children with Down's syndrome as well as the comparison group had a higher SOC when their stress level was lower (Hedov et al., 2002); and fathers of children with developmental disabilities reported lower levels of SOC more frequently and used strategies of avoidance compared to fathers with higher levels of SOC that used confrontation more frequently and positive reappraisal and problem solving behavior (Dabrowska, 2008).

In a study on parents of children with autism, the parents reported lower levels of SOC than the comparison group and used avoidance coping more often. Among parents of children with autism, the SOC level was positively associated with seeking social support and self-controlling and negatively with accepting responsibility and positive appraisal. The results demonstrated that the frequency of using accepting responsibility strategy increased with decreasing levels of SOC among the parents. This may suggest that one of the consequences of low SOC may be a self-blame tendency for the occurrence of stressful situations related to parenting a child with special needs (Pisula \& Kossakowska, 2010). This confirms earlier findings on lower levels of SOC among parents of children with autism (Olsson \& Hwang, 2002; Sivberg, 2002).

Several studies explored SOC in families of children with developmental disorders from birth to adolescence (ages 1-13, 0-16) and/or adulthood (ages 1-28). Hintermair (2004) studied 235 mothers of children aged 1-13 with hearing impairments and found that mothers with stronger SOC had an advantage in coping with the experience of raising a deaf and hard of hearing child over mothers with lower SOC scores. SOC was of greater importance than experienced social support. Similarly, Olsson and Hwang (2002) studied 429 fathers and mothers of children from birth to 16 years of age with and without intellectual disability (ID) and found that parents of children with ID who reported low levels of SOC were more depressed than control parents with low levels of SOC. No relation was found between the age of the child and the levels of SOC in parents of children with ID. In a study of children, adolescents and young adults with autism, Mak, Ho, and Kaw (2007) reported that mothers with a higher level of SOC reported less stress than those with lower levels of SOC. SOC had a moderating effect on the association between symptom severity and parenting stress.

In summary, the studies on families of children with special needs identified SOC as a significant protective factor related to effective coping and hopeful thinking that differentiated between families of children with typical development and families of children with special needs. Understanding the relationship between SOC and coping among parents of children with special needs provides insight into the mechanisms involved in parental adjustment and effective coping outcomes.

\section{SOC as Predictor of Health and Health Behavior}

In the past decade, research has shown the relationship between social factors, health and disease, focusing attention on salutogenic models, concentrating on personal control. This trend followed former studies that revealed that persons with a strong SOC tended to manage stress better, whereas persons with a poor SOC tended to be more sensitive to health challenges and illness (Lundberg \& Nystrom, 1994). Recent multiple researches on SOC and health have identified SOC as a predictor of health and health behavior (Berntsson \& Gustafsson, 2000; Bonanato et al., 2009; Forinder, Löf, \& Winiarski, 2005; Groholt, Stigum, Nordhagen, \& Kohler, 2003; Honkinen, Suominen, Valimaa, Helenius, \& Rautava, 2005; Jellesma, Rieffe, Terwogt, \& Kneepkens, 2006; Krause, 2011; Løndal, 2010; Nammontri, Robinson, \& Baker, 2013; Ray, Suominen, \& Roos, 2009; Torsheim, Aaroe, \& Wold, 2001).

Studies examined determinants of psychosomatic complaints in children and found that the predictors of psychosomatic complaints were mother's health, child's mental stability, contacts with peers, long-term illness, and, via other factors, parents' SOC, social competence, and school satisfaction (Berntsson \& Gustafsson, 2000). Furthermore, in an attempt to understand the relationship between poor perceived health during childhood and an individual's well-being throughout life, 1231 12-year-old school children in Finland were studied. SOC and variables of social support were found significantly associated with perceived health. Physical exercise and SOC were associated with perceived health and father's occupation and poor SOC was found to be independently associated with relatively poor health (Honkinen et al., 2005).

Studies focusing on the relation of somatic complaints and emotional functioning of children pinpointed attention at the existence of emotional problems in children who reported somatic complaints. Jellesma et al. (2006) studied 1538 8-13-year-old school children at three levels of somatic complaints (few, many, and clinical). The results showed that the clinical group and the children with many somatic complaints reported more negative moods on the anger, sadness, and fear scale, more difficulty differentiating emotions and a lower SOC than the group with fewer complaints. Torsheim et al. (2001) studied 1592 sixth grade children, 1534 eighth grade children, and 1605 tenth 
grade children in an attempt to tap the role of SOC and school-related stress as predictors of health complaints. Age group comparisons revealed that the association between SOC and stress grew weaker with age, whereas the direct association between SOC and health complaints grew stronger. Fifty two patients aged 9-22, who had stem cell transplant at least 3 years before the study, participated in a study of health and quality of life. The scores obtained on SOC for younger children (aged 9-12) showed that children in the SCT group have an SOC level equal to that of both the norm groups and other chronically ill children. The mean value for the younger children in the SCT group was in line with that of the norm group of children aged 9 (Forinder et al., 2005).

Parents' SOC and children's health. The parents' role in predicting their children's health and health behavior was examined based on the salutogenic model. The relation between parental SOC and child health was explored in a large-scale study (Groholt et al., 2003) in the five Nordic countries which included 9524 2-17-year-old children of which $35 \%$ co-responded with their parents due to their young age. Compared to the higher social classes, low levels of SOC were more common in the lower classes. The association of child chronic health complains with parental poor SOC was found to be disability specific (diabetes, epilepsy, and psychiatric problems). Parents of children with diabetes, epilepsy, or psychiatric problems had 2-5 higher odds of having poor SOC compared to parents of children without a specific diagnosis.

Ray et al. (2009) studied 772 parent-child dyads of 10-11-year-old school children in order to find the relationship between food intake and parents' SOC. Lower parental SOC was associated with children's irregular meal pattern, more frequent intake of energy-rich foods, and less frequent intake of nutrient-rich foods. In another study, mothers with lower levels of SOC were more likely to have children with decayed teeth or filled teeth regardless of the child's social class and gender (Bonanato et al., 2009).

In a study identifying the predictors of adaptation and assessing potential moderating effects of parents' sense of coherence and family hardiness on the relationship of severity of illness of a child with asthma, SOC and family hardiness predicted family adaptation. Icelandic mothers perceived their family's adaptation more favorably than American mothers. Regarding the fathers, family demands predicted adaptation. SOC moderated the effect of family demands on adaptation for both parents (Svavarsdottir, Rayens, \& McCubbin, 2005).

Intervention programs promoting children's health. In addition to identifying SOC as a significant protective factor related to effective coping, the contribution of the salutogenic paradigm in explaining successful coping with stressors and health promotion has guided the development of intervention programs promoting health and health behavior. The following studies are examples of such intervention programs involving children and their families.

An intervention program based on the salutogenic model promoting oral health resulted in improved oral health. The intervention provided evidence that SOC influenced oral health-related quality of life (Nammontri et al., 2013). Positive health beliefs and higher levels of SOC were found to predict positive health beliefs and fewer symptoms. An additional intervention program focused on promoting play in an after school program (ASP) had considerable potential of promoting the children's SOC. Most of the children in the study experienced their world as comprehensible, manageable, and meaningful. Negative thoughts and feelings were reduced during play. Play offered particularly strong opportunities for the children themselves to shape outcomes, and interact with children, promoting their SOC (Løndal, 2010)

In another intervention program that aimed to promote health resources in children, 226 5-10-year-old school children participated in a longitudinal self-worth reinforcement program. The results showed that developing SOC as a part of promoting mental health in school children is most effective during the early years of childhood. This finding emphasized the need to train professionals within the school (Krause, 2011).

\section{Conclusions and Future Research Directions}

The results of the surveyed studies support the conceptualization of the SOC construct as an important personal resource that develops during childhood. Stresses and challenges are a part of children's lives. However, most children who have a strong SOC can transform their potential resources into actuality, thereby promoting well-being. Children and adolescents with a high SOC may have a good comprehension of most of their contextual conditions, situational demands, and personal experiences. They may feel relatively in control of their lives and may possibly consider most of their tasks and participation in age appropriate activities as meaningful, significant, and worth of investing effort. When they face a stressful situation, they are able to select in a flexible manner the appropriate strategies to effectively cope with the stressors. Thus, acquiring a wide range of coping strategies, alongside an emphasis on collaborative activities, developing social partnerships that respect different voices and self-reliance, may enhance the youngsters' resilience and motivation to invest effort in order to reach their preferred goals (Margalit, 1998). Consistency, a special cognitive challenge for children, may strengthen comprehensibility; an overload-under load balance, a special risk for children who struggle with school 
demands, may affect manageability; and the participation in socially valued decision making may strengthen meaningfulness (Margalit, 2008).

The results of these studies have clear educational implications for school systems at various age groups in terms of prevention and intervention planning. The early manifestations of the developing SOC, as a personal resource, and the results that indicate that stresses and difficulties are disclosed in lower levels of SOC, call for early awareness and empowering programs within educational systems. In addition, the results that show the impact of effective intervention not only on better academic functioning, but also on friendship developing and significant growth in coherence, justify focused attempts on early intervention before SOC is structured and stabilized. The studies demonstrated the importance of early comprehensive intervention, as well as the significant value of preventive measures through sensitizing teachers not only to meet crises and difficulties, but especially to provide attentive support to the children's experiences. Preventive programs that empower children's abilities to integrate their thinking and learning skills with the abilities to regulate their feelings (emotion regulation) and actions (behavioral competence) promote growth, effort, and motivation (Idan \& Margalit, 2011). School-based intervention programs and teachers' training promoting salutogenic approaches in class are required alongside family-based interventions and parents' training to promote salutogenic approaches in the home.

In the reviewed studies, children with typical development and children with developmental disabilities, learning disabilities, and various additional adjustment challenges were included. Most children, who reported higher levels of loneliness, also experienced a low sense of coherence. In several studies, the low sense of coherence was related to children's current distress, as well as to early expressions of adjustment difficulties and to family climate. Mothers' sense of coherence was found as an important personal resource that enabled successful attachment relations and was related to children's sense of coherence (Al-Yagon \& Mikulincer, 2004). Special attention was provided to groups of children with developmental or contextual challenges that reported levels of sense of coherence compatible with their typical developing peers. Thus, the awareness of the fact that difficulties never appeared in isolation, encouraged the multidimensional prevention and intervention approaches that treated not only academic or behavior challenges, but supported the whole child who had been developing satisfactory social relations while struggling with difficulties, to support coping and celebrate success and competencies. The salutogenic paradigm provides a structure to this planning, by emphasizing comprehensibility (explaining and clarifying the goals and the procedures), manageability (teaching the required skills to reach these goals), and meaningfulness (enhancing motivation and involvement in the effort).

Research presented in this review demonstrated the importance of the salutogenic approach in developmental research of children and adolescents, and its potential for educational planning. The studies emphasized the interacting role of academic demands and social challenges with the SOC, clarifying the dynamic interactions between academic and socioemotional factors and children's readiness to treat their difficulties as challenges worthy of effort investment. These findings emphasized the major role of resilience approaches, considering SOC as a predictor in explaining well-being and adjustment, and calling for future development of comprehensive educational intervention programs (Idan \& Margalit, 2011).

In order to benefit schools and children from the salutogenic approach, two future research directions are needed. First, there is a need for longitudinal studies that will document changes and stabilities in the development of CSOC. Through longitudinal studies we are able to clarify the interactions between the stabilization and the flexibility of children's SOC within different contextual conditions. Second, research calls for cross-cultural comparisons of the sense of coherence development. There is a need for a coordinated international collaboration for longitudinal research to explore the interactions of SOC between cultures, families, schools, communities, and children's different growth paths.

Open Access This chapter is distributed under the terms of the Creative Commons Attribution-Noncommercial 2.5 License (http:// creativecommons.org/licenses/by-nc/2.5/) which permits any noncommercial use, distribution, and reproduction in any medium, provided the original author(s) and source are credited.

The images or other third party material in this chapter are included in the work's Creative Commons license, unless indicated otherwise in the credit line; if such material is not included in the work's Creative Commons license and the respective action is not permitted by statutory regulation, users will need to obtain permission from the license holder to duplicate, adapt or reproduce the material.

\section{References}

Al-Yagon, M. (2003). Children at-risk for developing learning disorders: Multiple perspectives. Journal of Learning Disabilities, 36(4), 318-335.

Al-Yagon, M. (2007). Socioemotional and behavioral adjustment among school-age children with learning disabilities: The moderating role of maternal personal resources. The Journal of Special Education, 40(4), 205-217.

Al-Yagon, M. (2008). Maternal personal resources and children's socio-emotional and behavioral adjustment. Child Psychiatry \& Human Development, 30, 283-298.

Al-Yagon, M. (2010). Maternal emotional resources and socioemotional well-being of children with and without learning disabilities. Family Relations, 59, 152-169. 
Al-Yagon, M. (2011). Fathers' coping resources and children's socioemotional adjustment among children with learning disabilities. Journal of Learning Disabilities, 44(6), 491-507.

Al-Yagon, M. (2012). Subtypes of attachment security in school-age children with learning disabilities. Learning Disability Quarterly, 35(3), 170-183.

Al-Yagon, M., \& Cinamon, G. R. (2008). Work-family relations among mothers of children with learning disorders. European Journal of Special Needs Education, 23, 91-107.

Al-Yagon, M., \& Margalit, M. (2006). Loneliness, sense of coherence and perception of teachers as a secure base among children with reading difficulties. European Journal of Special Needs Education, 21(1), 21-37.

Al-Yagon, M., \& Mikulincer, M. (2004). Socioemotional and academic adjustment among children with learning disorders: The mediational role of attachment-based factors. The Journal of Special Education, 38(2), 111-124.

Antonovsky, A. (1987). Unraveling the mystery of health. San Francisco: Jossey-Bass.

Berntsson, L. T., \& Gustafsson, J.-E. (2000). Determinants of psychosomatic complaints in Swedish schoolchildren aged seven to twelve years. Scandinavian Journal of Public Health, 28, 283-293.

Bonanato, K., Palva, S. M., Pordeus, I. A., Ramos-Jorge, M. L., Barbabela, D., \& Allison, P. J. (2009). Relationship between mothers' sense of coherence and oral health status of preschool children. Caries Research, 43, 103-109.

Cassidy, J. (1994). Emotion regulation: Influences of attachment relationships. In N. A. Fox (Ed.), The development of emotion regulation and dysregulation: Biological and behavioral aspects. Monographs of the Society for Research in Child Development, 59 (2-3, Serial No. 240), 228-249.

Cassidy, J., \& Shaver, P. R. (Eds.). (1999). Handbook of attachment: Theory, research, and clinical applications (pp. 89-111). New York: Guilford.

Dabrowska, A. (2003). Sense of coherence in parents of children with cerebral palsy. Psychiatria Polska, 41(2), 189-201.

Dabrowska, A. (2008). Sense of coherence and coping with stress in fathers of children with developmental disabilities. Polish Psychological Bulletin, 39(1), 29-34.

Damon, W. (2004). What is positive youth development? Annals of the American Academy of Political and Social Science, 591, 13-30.

Davidson, R. J., Lewis, M., Alloy, L. B., Amaral, D. G., Bush, G., Cohen, J., et al. (2002). Neural and behavioral substrates of mood and mood regulation. Biological Psychiatry, 52(6), 478-502.

Edwards, V. J., Holden, G. W., Felitti, V. J., \& Anda, R. F. (2003). Relationship between multiple forms of child maltreatment and adult mental health in community respondents: Results from the Adverse Childhood Experiences Study. The American Journal of Psychiatry, 160(8), 1453-1460.

Efrati-Virtzer, M., \& Margalit, M. (2009). Students' behaviour difficulties, sense of coherence and adjustment at school: Risk and protective factors. European Journal of Special Needs Education, 24(1), 59-73.

Einav, M., Levi, U., \& Margalit, M. (2012). Mothers' coping and hope in early intervention. European Journal of Special Needs Education, 27(3), 265-279.

Forinder, U., Löf, C., \& Winiarski, J. (2005). Quality of life and health in children following allogeneic SCT. Bone Marrow Transplantation, 36(2), 171-176.

Greenberg, M. T., Speltz, L., \& DeKlyan, M. (1993). The role of attachment in the early development of disruptive behavior problems. Development and Psychopathology, 5, 191-213.

Groholt, E.-K., Stigum, H., Nordhagen, R., \& Kohler, L. (2003). Is parental sense of coherence associated with child health? European Journal of Public Health, 13, 195-201.
Hedov, G., Anneren, G., \& Wikblad, K. (2002). Swedish parents of children with Down's syndrome. Scandinavian Journal of Caring Science, 16, 424-430.

Hintermair, M. (2004). Sense of coherence: A relevant resource in the coping process of others of deaf and hard of hearing children? Journal of Deaf Studies and Deaf Education, 9(1), 15-26.

Honkinen, P.-L. K., Suominen, S. B., Valimaa, R. S., Helenius, H. Y., \& Rautava, P. T. (2005). Factors associated with perceived health among 12-year-old school children. Scandinavian Journal of Public Health, 33, 35-41.

Idan, O., \& Margalit, M. (2011). The salutogenic orientation: Children's sense of coherence and hopeful thinking in education of children and adolescents. TEME, Special Issue, 24(4), 5-18.

Jellesma, F. C., Rieffe, C., Terwogt, M. M., \& Kneepkens, C. M. F. (2006). Somatic complaints and health care use in children: Mood, emotion awareness and sense of coherence. Social Science \& Medicine, 63, 2640-2648.

Krause, C. (2011). Developing sense of coherence in educational contexts: Making progress in promoting mental health in children. International Review of Psychiatry, 23(6), 525-532.

Liberman, L., Ratzon, N., \& Bart, O. (2013). The profile of performance skills and emotional factors in the context of participation among young children with Developmental Coordination Disorder. Research in Developmental Disabilities, 34(1), 87-94.

Løndal, K. (2010). Children's lived experience and their sense of coherence: Bodily play in a Norwegian after-school programme. Child Care in Practice, 16(4), 391-407.

Lundberg, P., \& Nystrom, F. H. (1994). Sense of coherence, social structure and health. European Journal of Public Health, 4, $252-257$.

Mak, W. W. S., Ho, A. H. Y., \& Kaw, R. W. (2007). Sense of coherence, parenting attitudes ad stress among mothers of children with autism in Hong Kong. Journal of Intellectual Disability Research, 20, 157-167.

Margalit, M. (1994). Loneliness among children with special needs: Theory, research, coping and intervention. New York: Springer.

Margalit, M. (1998). Loneliness and coherence among preschool children with learning disabilities. Journal of Learning Disabilities, 31(2), 173-180.

Margalit, M. (2003). Resilience model among individuals with learning disabilities (LD): Proximal and distal influences. Learning Disabilities Research \& Practice, 18(2), 82-86.

Margalit, M. (2008). The salutogenic paradigm in education: Promoting well-being of children and their families. Paper presented at the International Seminar on Salutogenesis, Helsinki, Finland.

Margalit, M., Al-Yagon, M., \& Kleitman, T. (2006). Family subtyping and early intervention. Journal of Policy and Practice in Intellectual Disabilities, 3(1), 33-41.

Margalit, M., \& Efrati, M. (1995). Loneliness, coherence and companionship among children with learning disorders. Educational Psychology, 16(1), 69-79.

Miller, J. G., \& Kinsbourne, M. (2012). Culture and neuroscience in developmental psychology: Contributions and challenges. Child Development Perspectives, 6(1), 35-41.

Most, T., Al-Yagon, M., Tur-Kaspa, H., \& Margalit, M. (2000). Phonological awareness, peer nominations, and social competence among preschool children at risk for developing learning disabilities. International Journal of Disability, Development \& Education, 47(1), 89-105.

Mowder, B. A., Rubinson, F., \& Yasik, A. E. (2009). Current status and future directions. In B. A. Mowder, F. Rubinson, \& A. E. Yasik (Eds.), Evidence based practice in infant and early childhood psychology (pp. 703-715). Hoboken, NJ: Wiley. 
Nammontri, O., Robinson, P. G., \& Baker, S. R. (2013). Enhancing oral health via sense of coherence: A cluster randomized trial. Journal of Dentistry Research, 92(1), 26-31.

National Scientific Council on the Developing Child. (2004). Children's emotional development is built into the architecture of their brains. (Working paper 2). Retrieved from Center on the Developing Child website http://www.developingchild.harvard.edu National Scientific Council on the Developing Child. (2012). Establishing a level foundation for life: Mental health begins in early childhood. (Working paper 6). Retrieved from Center on the Developing Child website http://www.developingchild.harvard.edu

Natvig, G. K., Hanestad, B. R., \& Samdal, O. (2006). The role of the student: Salutogenic or pathogenic? International Journal of Nursing Practice, 12(5), 280-287.

Oelofsen, N., \& Richardson, P. (2006). Sense of coherence and parenting stress in mothers and fathers of preschool children with developmental disability. Journal of Intellectual \& Developmental Disability, 31(1), 1-12.

Olson, D. H. (1986). Circumplex model VII: Validation studies and FACES III. Family Process, 26, 337-351.

Olson, D. H. (2000). Circumplex model of marital and family systems. Journal of Family Therapy, 22, 144-167.

Olsson, M. B., \& Hwang, C. P. (2002). Sense of coherence in parents of children with different developmental disabilities. Journal of Intellectual Disability Research, 46(7), 548-559.

Pisula, E., \& Kossakowska, Z. (2010). Sense of coherence and coping with stress among mothers and fathers of children with autism. Journal of Autism \& Developmental Disorders, 40, 1485-1494.

Ray, C., Suominen, S., \& Roos, E. (2009). The role of parent's sense of coherence in irregular meal pattern and food intake pattern of children aged 10-11 in Finland. The Journal of Epidemiology and Community Health, 63(12), 1005-1009.
Reid, J. B., Patterson, G. R., \& Snyder, J. (2002). Antisocial behavior in children and adolescents: A developmental analysis and model for intervention. Washington, DC: American Psychological Association.

Rubin, K., Bukowski, W., \& Parker, J. (2006). Peer interactions, relationships, and groups. In W. Damon \& R. M. Lerner (Eds.), Handbook of child psychology (6th ed.): Vol. 3: Social, emotional, and personality development (N. Eisenberg, Vol. Ed.) (pp. 571-645). New York: Wiley.

Sharabi, A., Levi, U., \& Margalit, M. (2012). Children's loneliness, sense of coherence, family climate and hope: Developmental risk and protective factors. The Journal of Psychology, 146(1-2), 61-83.

Sivberg, B. (2002). Family system and coping behaviors. Autism, 6(4), 397-409.

Svavarsdottir, E. K., Rayens, M. K., \& McCubbin, M. (2005). Predictors of adaptation in Icelandic and American families of young children with chronic asthma. Family \& Community Health, 28(4), 338-350.

Thompson, R. A. (2001). Development in the first years of life. The Future of Children, 11(1), 20-33.

Thompson, R. A., \& Lagattuta, K. (2006). Feeling and understanding: Early emotional development. In K. McCartney \& D. Phillips (Eds.), The Blackwell handbook of early childhood development (pp. 317-337). Oxford, UK: Blackwell.

Torsheim, T., Aaroe, L. E., \& Wold, B. (2001). Sense of coherence and school related stress as predictors of subjective health complaints in early adolescence: Interactive, indirect or direct relationships? Social Science \& Medicine, 53, 603-614.

Yugar, J. M., \& Shapiro, E. S. (2001). Elementary children's school friendship: A comparison of peer assessment methodologies. School Psychology Review, 30(4), 568. 